\title{
Dampak Riba Menurut Al-Quran dan Hadits
}

\author{
Rachmad Risqy Kurniawan, SEI, MM \\ Sekolah Tinggi Ilmu Ushuluddin Darul Qur'an, Bogor \\ Email : rah.rizqy@gmail.com
}

\begin{abstract}
The purpose of this study is to examine more deeply the impact of the practice of interest or usury based on the verses of the Qur'an and its interpretations and Hadith. This research is library research with the maudhu'i (thematic) interpretation method. The results of this study indicate that the practice of interest is usury which is prohibited by Allah SWT in the Al-Quran and Hadith. The prohibition is caused by the bad effects it causes, among others: Riba will not increase wealth (Surah al-Rum verse 39); Riba plunges people into a painful punishment as inflicted on the Jews (Surah an-Nisa verses 160-161); Riba has an impact on failure or fall or collapse or sadness and or distress (Surah Ali 'Imran verse 130); Riba has an impact on the human psyche, has an impact on his property, namely destroyed/perished/destroyed/vanished/depreciated in value, and has an impact on him, namely being fought by Allah SWT and His Messenger (Surah al-Baqarah verses 275, 276, 278, 279 and 280); The usury eaters, usury depositors, usury transaction writers and witnesses who witness usury transactions are cursed (Shohih Muslim No; 1598); Riba brings punishment to a country not only to the eater (Shohih Al-Jami 'No; 279); Riba damages the honor of others (Shohih wa Dhoif At-Thargib wat Tarhib No; 2833); Riba leads to poverty (Shohih Al-Jami 'No: 5518 and Sunan Ibn Maajah Hadith No; 2279); Riba brings famine or drought (Shohih wa Dhoif At-Thargib wat Tarhib No:1343).
\end{abstract}

Keywords : Usury, Quran, Hadits

Abstrak : Tujuan penelitian ini adalah untuk mengkaji lebih mendalam mengenai dampak praktik bunga atau riba berdasarkan ayat-ayat Al-Quran beserta tafsirnya dan Hadits. Penelitian ini merupakan penelitian kepustakaan (library research) dengan metode penafsiran maudhu'i (tematik). Hasil Penelitian ini menunjukkan bahwa praktik bunga adalah riba yang dilarang oleh Allah SWT dalam Al-Quran dan Hadits. Larangan itu disebabkan karena dampak buruk yang ditimbulkannya antara lain: Riba tidak akan menambah harta (Surat al-Rum ayat 39); Riba menjerumuskan orang kedalam azab yang pedih sebagaimana yang ditimpakan kepada orang-orang yahudi (Surat an-Nisa ayat 160-161); Riba berdampak pada kegagalan atau kejatuhan atau keruntuhan atau kesedihan dan atau kesusahan (Surat Ali 'Imran ayat 130); Riba berdampak pada kejiwaan manusia, berdampak pada hartanya yaitu hancur/binasa/musnah/lenyap/merosot nilainya, dan berdampak pada dirinya yaitu diperangi Allah SWT dan rasul-Nya (Surat al-Baqarah ayat 275, 276, 278, 279 dan 280); Pemakan riba, penyetor riba, penulis transaksi riba dan saksi yang menyaksikan transaksi riba dilaknat (Shohih Muslim No; 1598); Riba mendatangkan azab kepada suatu negeri bukan hanya kepada pemakannya saja (Shohih Al-Jami' No; 279); Riba merusak kehormatan orang lain (Shohih wa Dhoif At-Thargib wat Tarhib No; 2833); 
Riba menjerumuskan kepada kemiskinan (Shohih Al-Jami' No: 5518 dan Sunan Ibnu Maajah Hadits No; 2279); Riba mendatangkan paceklik atau kekeringan (Shohih wa Dhoif At-Thargib wat Tarhib No:1343).

\section{Kata Kunci : Riba, Al-Quran, Hadits}

\section{Pendahuluan}

Secara etimologi dan terminologi riba (riba nasiah) adalah tambahan/kelebihan bayar dalam transaksi utang piutang. ${ }^{1}$ Riba sudah sejak lama ada bahkan sebelum zaman jahiliyah. Bahkan untuk membolehkan perilaku riba ini orang-orang kafir musyrik jahiliyah mengatakan bahwa riba sama dengan jual-beli, yaitu sama-sama dibolehkan hukumnya dan sama-sama mendatangkan keuntungan, ${ }^{2}$ padahal Allah SWT mengharamkan hukum riba dan menghalalkan hukum jual beli, hal ini secara tegas Allah SWT jelaskan dalam Firman-Nya Al-Quran Surat Al-Baqarah ayat 275.

Kemiskinan, tingkat pendidikan yang rendah, ketidaktersediaan lapangan pekerjaan, penghasilan yang tidak layak dan terus naiknya harga bahan pokok sudah menjadi momok ditengah masyarakat Indonesia, sehingga membuat kondisi keterpaksaan bagi mereka untuk sekedar memenuhi kebutuhan dasarnya dengan cara berutang, namun sayangnya dalam kondisi demikian terpuruk, ditambah pula dengan jeratan bunga utang yang semakin mencekik. Ibarat peribahasa sudah jatuh tertimpa tangga pula.

Kondisi itu diperparah lagi dengan kondisi perekonomian Indonesia yang sulit keluar dari middle income trap, Defisit neraca pembayaran, beban hutang luar negeri yang membengkak, investasi yang tidak efisien, dan banyak indikator ekonomi lainnya telah berperan aktif dalam mengundang munculnya krisis ekonomi yang menambah beban masyarakat.

Maka, untuk mengurai masalah-masalah diatas tentunya harus dimulai dari akar masalahnya, yaitu penerapan sistem ekonomi berdasarkan bunga, untuk itu sebagai umat muslim, seyogyanya harus kembali kepada ajaran Al-Quran dan Haditst sebagai rujukan utama kehidupan, termasuk dalam kehidupan berekonomi, yaitu bagaimana caranya untuk keluar dari jeratan lingkar masalah ekonomi diatas, salah satunya dengan menerapkan sistem ekonomi syariah atau ekonomi Islam adyang dapat menjadi solusi bukan menambah masalah.

Ekonomi merupakan bagian integral dari ajaran Islam dan karenanya ekonomi syariah akan terwujud hanya jika ajaran Islam diyakini dan dilaksanakan secara menyeluruh. ${ }^{3}$ Ekonomi syariah mempelajari perilaku ekonomi individu-individu yang secara sadar dituntun oleh ajaran Islam Al-Qur'an dan Sunnah dalam memecahkan masalah ekonomi yang dihadapi. Berbagai ahli ekonomi muslim memberikan definisi ekonomi Islam yang bervariasi, diantaranya ada yang mengungkapkan bahwa Ekonomi

\footnotetext{
${ }^{1}$ Tho'in, Muhammad, Larangan Riba Dalam Teks Dan Konteks (Studi Atas Hadits Riwayat Muslim Tentang Pelaknatan Riba), Jurnal Ilmiah Ekonomi Islam Vol. 02 No. 02, Juli, 2016

${ }^{2}$ Abdul Ghofur, Konsep Riba Dalam Al-Qur'an, Jurnal Economica Volume VII/Edisi 1/Mei 2016

${ }^{3}$ Akmal,. Abidin, Zainal, Korelasi Antara Islam dan Ekonomi, Jurnal Penelitian, Vol. 9, No. 1, Februari 2015
} 
Islam adalah kumpulan dari dasar-dasar umum ekonomi yang diambil dari Al-Qur'an dan Sunnah Rasulullah SAW serta dari tatanan ekonomi yang dibangun atas dasardasar tersebut sesuai dengan berbagai macam. Adapula yang mendefinisikan bahwasanya ekonomi Islam adalah ilmu yang mempelajari usaha-usaha manusia untuk mengalokasikan dan mengelola sumber daya untuk mencapai keberuntungan berdasarkan pada prinsip dan nilai-nilai Al-Qur'an dan Sunnah. ${ }^{4}$

Berdasarkan ajaran ekonomi syariah yang berdasarkan Al-Quran dan Haditst, pelarangan riba merupakan solusi dari akar masalah perekonomian, karena dampak riba yang buruk dan menimbulkan lingkar "setan" masalah sosial-ekonomi ditengah masyarakat. ${ }^{5}$ Sehingga dalam penelitian ini akan dikaji lebih mendalam mengenai dampak praktik bunga atau riba berdasarkan ayat-ayat Al-Quran beserta tafsirnya dan Hadits. Penelitian ini merupakan penelitian kepustakaan (library research) dengan menggunakan literatur (kepustakaan) antara lain Al-Quran dan kitab tafsirnya sebagai sumber primer dan artikel ilmiah pendukung lainnya sebagai sumber sekunder, dengan metode penafsiran maudhu'i (tematik) yaitu penelitian ini masuk dalam kategori penulisan karya tafsir yang struktur pemaparannya mengacu pada tema tertentu atau pada ayat, surat atau juz tertentu yang ditentukan oleh penafsir sendiri. ${ }^{\mathbf{6}}$

\section{Dampak Riba Menurut Al-Quran \\ 1. Riba tidak akan menambah harta}

Dampak riba menurut Al-Quran yang pertama yaitu apa yang pertama kali diturunkan kepada Rasulullah SAW tentang riba ini, yaitu bahwa riba tidak akan menambah harta sebagaimana dalam surat al-Rum ayat 39, sebagaimana berikut:

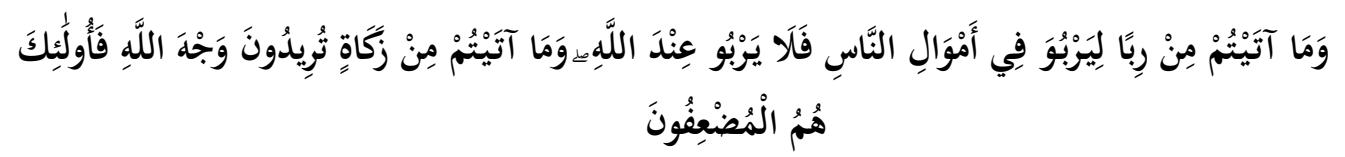

Artinya: Dan sesuatu riba (tambahan) yang kamu berikan agar harta manusia bertambah, maka tidak bertambah dalam pandangan Allah. Dan apa yang kamu berikan berupa zakat yang kamu maksudkan untuk memperoleh keridaan Allah, maka itulah orang-orang yang melipatgandakan (pahalanya) (al-Rum: 39).

Ayat ini diturunkan di Mekah sebelum Nabi Hijrah, secara tekstual tidak ada pelarangan riba dalam ayat ini. Tetapi yang ada hanya isyarat akan kemurkaan Allah terhadap riba itu, karena riba itu tidak ada pahalanya di sisi Allah, jadi dengan demikian ayat ini memberikan peringatan supaya berhenti dari perbuatan riba. Meskipun belum jelas dinyatakan bahwa riba adalah dilarang, ayat yang diturunkan di Mekah itu mengajarkan bahwa Allah membenci riba dengan menganjurkan zakat. Hal ini untuk mempersiapkan agar pada saatnya riba dengan secara jelas-jelas dinyatakan haram maka akan mudah di taati. Meskipun ayat-ayat makiyah belum mengajarkan hukum

\footnotetext{
${ }^{4}$ Arif, Muhammad, Filsafat Ekonomi Islam. Fakultas Ekonomi dan Bisnis Islam. UIN Sumatera Utara, Buku DIKTAT, 2018

${ }^{5}$ Amin, Ahmad Riawan, Satanic Finance Bikin Umat Miskin, Jakarta: : Zaytuna Ufuk Abadi, 2012

${ }^{6}$ Sanaky, Hujair A. H., Metode Tafsir (Perkembangan Metode Tafsir Mengikuti Warna atau Corak Mufassirin), Al-Mawarid Edisi XVIII Tahun 2008
} 
secara terperinci namun masalah riba telah disinggung, yang berarti bahwa mu'amalah ribawiyah memang tidak sejalan dengan nilai-nilai keutamaan dan kebaikan. ${ }^{7}$

At-Thabari menafsirkan ayat ini bahwa apa yang telah kalian berikan satu sama lain sebagai hadiah, untuk meningkatkan uang si pemberi dengan mengharapkan pengembalian hadiahnya kepadanya, maka tidak bertambah dalam pandangan Allah, Karena memberikan hadiah tersebut untuk mendapatkan kelebihan dari orang lain bukan karena berharap Ridha Allah SWT. Ibnu Abbas menafsirkan bahwa si pemberi riba ingin mengharapkan pengembalian lebih banyak dari apa yang diberikan. Mujahid juga menafsirkan riba dalam ayat ini adalah hadiah. ${ }^{8}$

Sedangkan menurut Al-Qurthubi, yang dimaksud dalam ayat ini adalah tambahan riba dalam utang-piutang/pinjaman, orang yang memberikan pinjaman mengharapkan hartanya akan bertambah dengan tambahan atas pinjamannya yang disebut riba, namun sesungguhnya tidak bertambah disisi Allah SWT. ${ }^{9}$

Sedangkan menurut Ibnu Katsir, barangsiapa yang memberikan hadiah dan menginginkan orang untuk mengembalikan kepadanya lebih dari yang dia berikan kepada mereka, maka ini tidak ada balasannya di sisi Allah, sebagaimana yang dijelaskan oleh Ibn Abbas, Mujahid, Al-Dahhak, Qatadah, Ikrimah, Muhammad bin Ka'b dan Al -Sha'bi, meskipun demikian perbuatan ini diperbolehkan, meskipun tidak ada balasan untuk itu kecuali apa yang telah diberikan. Menurut Al-Dahhak, ayat ini adalah permulaan sebelum dilarangnya riba secara khusus, dimana dalam ayat ini meskipun tidak ada pelarangan secara jelas namun ada isyarat bahwa perbuatan riba ini tidak mendapatkan pahala dan dibenci Allah SWT, sebagaimana dikuatkan dalam ayat

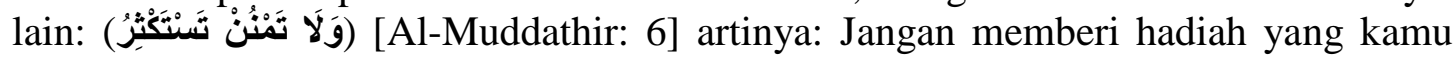
inginkan lebih dari itu. ${ }^{10}$

Berdasarkan tafsir para mufassirin diatas maka dapat ditarik kesimpulan bahwa riba tidak akan menambah harta justru akan mengurangi keberkahan dari harta.

\section{Riba menjerumuskan orang kedalam azab yang pedih sebagaimana yang ditimpakan kepada orang-orang yahudi}

Dampak riba selanjutnya adalah Surat an-Nisa ayat 160-161, ayat ini diturunkan di Madinah, sebagai tahapan selanjutnya dari pelarangan riba sebagaimana sudah dimulai dengan tahapan pertama diatas, Allah SWT berfirman:

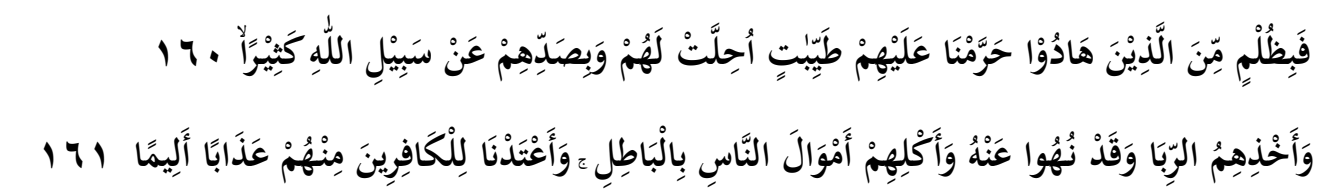

Artinya: 160. Maka disebabkan kezaliman orang-orang Yahudi, kami haramkan atas mereka (memakan) yang baik-baik (yang dahulunya) dihalalkan bagi

\footnotetext{
${ }^{7}$ Oom Mukaromah, Interpretasi Ayat-Ayat Riba Dalam Kajian Tafsir Maudhu'i, Al-Qalam Vol 21, No.100 (Januari-April 2004)

${ }^{8}$ Al-Ṭhabarī, Abu Ja“efar Muḥammad Ibn Jarīr Ibn Yazīd Ibn Kathir Ibn Gālib . Jāmi’u al-Bayān fĩ Ta`wīli al-Qur'ān (Beirut: Daarul Kitab, 1412 H/1992 M)

${ }^{9}$ Al-Qurthubi, Ahmad Muhammad bin. Al-Jāmi’ Li Ahkām Al-Qur'an. Bairut-Libnan: Muassasah alRisālah, 2006

${ }^{10}$ Ibnu Katsir, Tafsir al-Qur'an al-Adzim (Beirut : Daar al-Fikr, 1923)
} 
mereka, dan karena mereka banyak menghalangi (manusia) dari jalan Allah. 161. Dan disebabkan mereka memakan riba, padahal sesungguhnya mereka telah dilarang daripadanya, dan karena mereka memakan harta orang dengan jalan yang bathil. Kami telah, menyediakan untuk orang-orang kafir diantara mereka itu siksa yang pedih (An-Nisa: 160-161).

Ayat ini merupakan pelajaran yang dikisahkan Allah kepada kita tentang perilaku Yahudi yang dilarang melakukan riba, tetapi justru mereka memakannya, bahkan menghalalkannya, maka sebagai akibat dari itu semua, mereka itu mendapat laknat dan kemurkaan Allah. ${ }^{11}$

Menurut At-Thabari, ayat ini menjelaskan perilaku umat yahudi yang mengambil kelebihan dari pokok harta yang dipinjamkan kepada orang lain karena memperpanjang jangka waktu pengembalian pinjamannya, kemudian perilaku ini diharamkan oleh Allah. ${ }^{12}$

Sedangkan menurut Al-Qurthubi, pengharaman riba disebabkan atas ketidakadilan yang orang-orang yahudi timbulkan pada zaman dahulu, sehingga menjadi pelajaran pengharaman riba pada masa sekarang. Umat yahudi sesungguhnya telah dilarang mempraktekkan riba ini di dalam taurat yang diturunkan kepada Musa AS namun mereka mereka mengubah, memutarbalikkan, tidak taat bahkan mengingkari ketetapan Allah ini, sehingga perilaku riba ini semakin marak terjadi sampai Allah menurunkan azabnya kepada umat yahudi. Sehingga dapat ditarik kesimpulan bahwa azab pedih yang ditimpakan kepada umat yahudi disebabkan dosadosa mereka khususnya dosa riba. ${ }^{13}$

Sedangkan menurut Ibnu Katsir, bahwa Allah telah melarang mereka dari riba, namun mereka tetap menarik dan mengambilnya, mereka membuat tipu daya dengan berbagai macam tipu daya dan jenis kerancuan sehingga terlihat bukan riba padahal sesungguhnya riba, karena perilaku mereka inilah yang suka menghalalkan apa yang Allah haramkan dengan mengubah-ubah istilah dan segala tipu daya sehingga Allah timpakan azab yang pedih kepada mereka. ${ }^{14}$

Menurut As-sa'di menafsirkan ayat ini, bahwa umat yahudi mencegah orang miskin dari mendapatkan keadilan karena perilaku mereka yang mengambil riba dari setiap pinjaman mereka kepada orang miskin, maka Allah haramkan apa yang baikbaik yang sebelumnya Allah halalkan bagi mereka dan menimpakan azab yang pedih kepada mereka. ${ }^{15}$

\footnotetext{
${ }^{11}$ Oom Mukaromah, Interpretasi Ayat-Ayat Riba Dalam Kajian Tafsir Maudhu'i, Al-Qalam Vol 21, No.100 (Januari-April 2004)

12 Al-Ṭhabarī, Abu Ja far Muḥammad Ibn Jarīr Ibn Yaz̄id Ibn Kathir Ibn Gālib . Jāmi’u al-Bayān fī Ta`wīli al-Qur`ān (Beirut: Daarul Kitab, 1412 H/1992 M)

${ }^{13}$ Al-Qurthubi, Ahmad Muhammad bin. Al-Jāmi’ Li Ahkām Al-Qur'an. Bairut-Libnan: Muassasah alRisālah, 2006

${ }^{14}$ Ibnu Katsir, Tafsir al-Qur'an al-Adzim (Beirut : Daar al-Fikr, 1923)

${ }^{15}$ As-Sa'di, Syaikh Abdurrahman bin Nashir. Taisirul Karimirrahman fi Tafsiri Kalamil Mannan. Cet. I; Baerut: Dar Ibn Hazm, 2003.
} 
Berdasarkan tafsir para mufassirin diatas maka sangat jelas bahwa riba berdampak azab Allah kepada manusia sebagaimana yang Allah timpakan kepada umat yahudi.

\section{Riba berdampak pada kegagalan atau kejatuhan atau keruntuhan atau kesedihan dan atau kesusahan.}

Tahapan selanjutnya dari pelarangan riba adalah pelarangan atas sebagian bentuknya yaitu jika riba itu diambil dengan berlipat-lipat ganda, sebagaimana firman Allah SWT dalam Surat Ali 'Imran ayat 130:

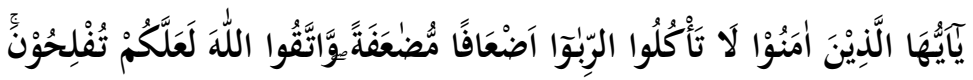

Artinya: Hai orang-orang yang beriman, janganlah kamu memakan riba dengan berlipat ganda dan bertakwalah kamu kepada Allah supaya kamu mendapat keberuntungan. ( Ali Imran: 130 ).

As-sa'di menafsirkan ayat ini dengan meninggalkan apa yang seharusnya ditinggal yaitu riba yang berlipat-lipat ganda, maka Allah SWT akan membalasnya dengan keberuntungan dan keberuntungan seorang manusia adalah surga Allah SWT. Sementara itu, kekafiran dan kemaksiatan mempunyai derajat yang berbeda-beda, dosa besar yaitu dosa riba dapat menjadi sebab kekafiran. Sehingga dapat disimpulkan dosa riba karena termasuk dosa besar akan mendekatkan seseorang kedalam kekafiran sehingga Allah membalasnya dengan nerakanya. ${ }^{\mathbf{1 6}}$

At-Thabari menafsirkan bahwa riba yang dimaksud dalam ayat ini adalah riba jahiliyah begitu pula menurut tafsir mujahid, bahwa riba jahiliyah inilah yang dilarang yaitu riba yang berlipat-lipat ganda, yang marak terjadi pada orang orang musrik jahiliyah sebelum turunnya risalah keislaman, riba dalam bentuk jahiliyah ini adalah riba yang berlipat ganda sepanjang waktu, artinya semakin panjang waktu pelunasan riba maka semakin banyak pula riba yang diambil, maka dengan turunnya ayat ini, riba jenis ini yaitu riba jahiliyah yang sebelumnya marak mereka ambil dan makan, dilarang dalam Islam. Jika mereka bertakwa kepada Allah yaitu dengan meninggalkan riba maka mereka akan mendapatkan keberuntungan, sebaliknya jika mereka tetap mengambil dan memakan riba jahiliyah setelah diharamkan maka bagi mereka kegagalan atau kejatuhan atau keruntuhan atau kesedihan dan atau kesusahan. ${ }^{17}$

As-Syaukani menafsirkan ayat ini, bahwa kekafiran kaum kafir jahiliyah salah satunya disebabkan karena mereka menghalalkan riba pada masa jahiliyah, kemudian setelah dilarang dalam Islam, namun mereka tetap mempraktekkan riba, maka riba dapat menghilangkan keimanan, sehingga balasan bagi mereka hanyalah neraka. ${ }^{\mathbf{1 8}}$ Menurut Al-Baghawi, yang dimaksud ketakwaan dalam ayat ini adalah takwa dengan menghindari memakan riba sehingga mendapatkan keberuntungan, sebaliknya dengan tetap memakan riba maka akan mendapatkan kegagalan. ${ }^{19}$ Menurut tafsir jalalain, balasan dari meninggalkan riba adalah keberuntungan yang dalam ayat ini dapat

${ }^{16}$ As-Sa'di, Syaikh Abdurrahman bin Nashir. Taisirul Karimirrahman fi Tafsiri Kalamil Mannan. Cet. I; Baerut: Dar Ibn Hazm, 2003.

17 Al-Ṭhabarī, Abu Ja far Muḥammad Ibn Jarīr Ibn Yazīd Ibn Kathir Ibn Gālib . Jāmi’u al-Bayān fī Ta`wīli al-Qur`ān (Beirut: Daarul Kitab, 1412 H/1992 M)

${ }^{18}$ As-Syaukani, Muhammad bin Muhammad 'Alî bin Muhammad, Fathul Qodir al-Jami' Baina Fannair Riwayah Wad-Diroyah Min Ilmit Tafsir, Kairo:Darul Hadits, 1992

${ }^{19}$ Al-Baghawi, Al-Husain bin Masúd. Ma’alim al-Tanzil,. Jilid. 1. Riyad: Dar al-Taybah, 1409. 
ditafsirkan kemenangan yaitu kemenangan dari peperangan melawan riba sebagaimana dalam Surat al-Baqarah ayat 279 yang akan ditafsirkan setelah ini. ${ }^{\mathbf{2 0}}$

Berdasarkan tafsir para mufassirin diatas maka sangat jelas bahwa riba berdampak kegagalan atau kejatuhan atau keruntuhan atau kesedihan dan atau kesusahan kepada manusia sebagaimana yang Allah timpakan kepada kaum musyrik kafir jahiliyah.

\section{Riba berdampak pada kejiwaan manusia, berdampak pada harta manusia yaitu hancur/binasa/musnah/lenyap/merosot nilainya, dan berdampak diperangi Allah SWT dan rasul-Nya}

Tahapan terakhir dari pelarangan riba adalah pelarangan seluruh jenis riba, sebagaimana dalam firman Allah SWT dalam Surat al-Baqarah ayat 275, 276, 278, 279 dan 280:

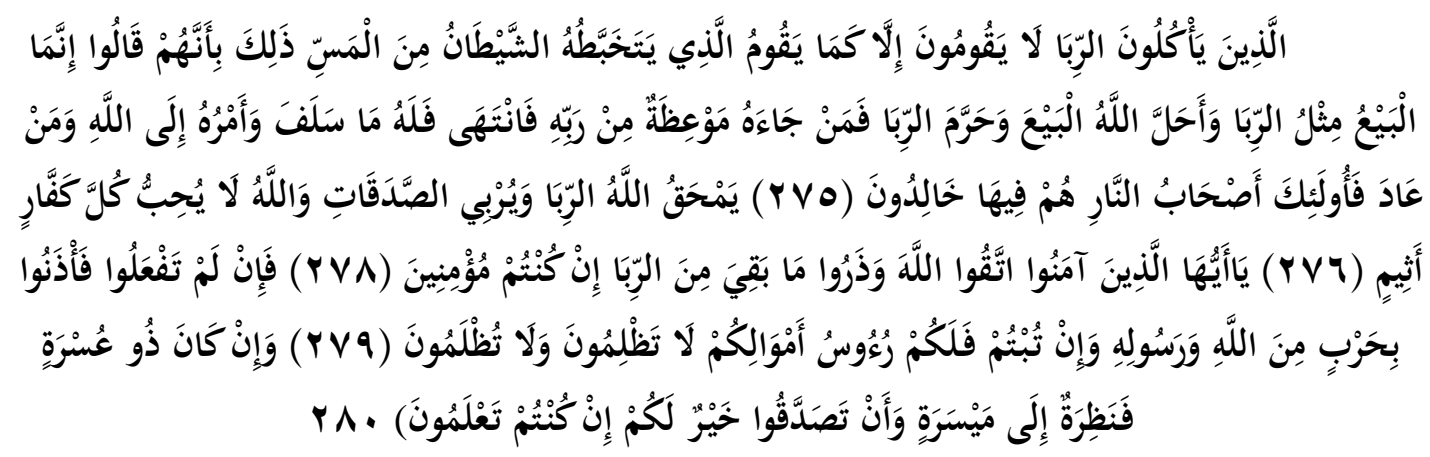

Artinya: 275. Orang-orang yang memakan riba tidak dapat berdiri melainkan seperti berdirinya orang yang kemasukan setan karena gila. Yang demikian itu karena mereka berkata bahwa jual beli sama dengan riba. Padahal Allah telah Menghalalkan jual beli dan Mengharamkan riba. Barangsiapa mendapat peringatan dari Tuhan-nya, lalu dia berhenti, maka apa yang telah diperolehnya dahulu menjadi miliknya dan urusannya (terserah) kepada Allah. Barangsiapa mengulangi, maka mereka itu penghuni neraka, mereka kekal di dalamnya. 276. Allah Memusnahkan riba dan Menyuburkan sedekah. Allah tidak menyukai setiap orang yang tetap dalam kekafiran dan bergelimang dosa. 278. Wahai orang-orang yang beriman! Bertakwalah kepada Allah dan tinggalkan sisa riba (yang belum dipungut) jika kamu orang beriman. 279. Jika kamu tidak melaksanakannya, maka umumkanlah perang dari Allah dan RasulNya. Tetapi jika kamu bertobat, maka kamu berhak atas pokok hartamu. Kamu tidak berbuat zalim (merugikan) dan tidak dizalimi (dirugikan). 280. Dan jika (orang berutang itu) dalam kesulitan, maka berilah tenggang waktu sampai dia memperoleh kelapangan. Dan jika kamu menyedekahkan, itu lebih baik bagimu, jika kamu mengetahui.

Dalam kitab tafsir Shafwatut Tafasir, Orang-orang yang makan (mengambil) riba tidak dapat berdiri melainkan seperti berdirinya kemasukan setan lantaran (tekanan) penyakit gila." Orang-orang yang berinteraksi dengan riba dan menghisap 'darah' manusia, mereka tidak dapat berdiri di Hari Kiamat, melainkan seperti berdirinya orang yang menderita penyakit ayan ketika kambuh. Mereka bangkit dan

${ }^{20}$ Al-Mahally, Imam Jalaluddin dan Imam Jalaluddin As-suyutti, Tafsir Jalalain Berikut Asbab AnNuzulnya, Bandung,: Sinar Baru, 1990 
terjatuh dan tidak mampu berdiri dengan tegak, mereka berjalan sempoyongan, itu merupakan balasan bagi mereka.

Keadaan mereka yang demikian itu, adalah disebabkan mereka berkata (berpendapat), sesungguhnya jual beli itu sama dengan riba," keadaan jatuh-bangun mereka di Hari Kiamat disebabkan karena mereka menghalalkan apa yang diharamkan Allah. Mereka mengatakan bahwa riba seperti jual-beli, mengapa diharamkan ? Allah berfirman sebagai bantahan untuk mereka : "Padahal Allah telah menghalalkan jual beli dan mengharamkan riba." Allah menghalalkan jual-Beli karena ada transaksi tukar menukar hal-hal yang bermanfaat, dan mengharamkan riba karena dapat membahayakan individu dan masyarakat. Riba merupakan kelebihan harta hasil jerihpayah orang si penghutang. Maka Barang siapa datang kepadanya pengajaran dari Tuhannya, lalu berhenti, maka menjadi kepunyaan apa yang telah diambil. Dan urusannya terserah kepada Allah dan barangsiapa kembali lagi memakan riba maka itulah penghuni-penghuni neraka, mereka kekal di dalamnya.

Allah memusnahkan riba dan menyuburkan sedekah, Allah tidak menyukai orang yang sangat mengingkari nikmat Allah dan terus menerus mengerjakan dosa. Ayat ini menandakan bahwa perbuatan riba mendekati kekafiran. ${ }^{21}$

At-Thabari menafsirkan dampak dari memakan riba, pemakannya bangkit dari kubur seperti orang yang gila karena dicekik setan, pemakan riba juga berkurang hartanya bahkan musnah, dan bagi pemakan riba wajib untuk diperangi, sehingga dapat disimpulkan bahwa riba berdampak buruk bagi jiwa, harta dan diri manusia, pada jiwanya menjadi gila, pada hartanya menjadi berkurang dan bahkan musnah, dan pada dirinya yaitu diperangi hingga mati. ${ }^{22}$

Al-Qurthubi menafsirkan bahwa pemakan riba itu seperti orang serakah yang tidak akan puas, selalu merasa kurang hingga selalu gelisah. ${ }^{\mathbf{2 3}}$

Ibnu Katsir menafsirkan bahwa pemakan riba itu seperti orang yang menderita penyakit epilepsi, dan pemakan riba juga berakhir dengan kemiskinan. ${ }^{24}$

As-Sa'di menafsirkan bahwa pemakan riba ketika berfikir maka fikiran mereka sesat, impian mereka jatuh dan pendapat mereka melemah, dan mereka menjadi dalam penampilan dan gerakan mereka seperti orang gila dalam ketidakteraturan dan keterasingan baik dalam pikiran maupun moral mereka. ${ }^{25}$

Al-Baghawi menafsirkan bahwa pemakan riba seperti orang gila. Dan pemakan riba harta berkurang, musnah, dan hilang keberkahannya, dan menurut Al-Baghawi

\footnotetext{
${ }^{21}$ Ash-Shabuni, Syaikh Muhammad Ali, Shafwatut Tafasir Tafsir-Tafsir Pilihan, Jakarta, Pustaka AlKautsar, 2020.

${ }^{22}$ Al-Ṭhabarī, Abu Ja far Muḥammad Ibn Jarīr Ibn Yaz̄̄d Ibn Kathir Ibn Gālib . Jāmi’u al-Bayān fì Ta`wīli al-Qur’ān (Beirut: Daarul Kitab, 1412 H/1992 M)

${ }^{23}$ Al-Qurthubi, Ahmad Muhammad bin. Al-Jāmi’ Li Ahkām Al-Qur'an. Bairut-Libnan: Muassasah alRisālah, 2006

${ }^{24}$ Ibnu Katsir, Tafsir al-Qur'an al-Adzim (Beirut : Daar al-Fikr, 1923)

${ }^{25}$ As-Sa'di, Syaikh Abdurrahman bin Nashir. Taisirul Karimirrahman fi Tafsiri Kalamil Mannan. Cet. I; Baerut: Dar Ibn Hazm, 2003.
} 
berperang dengan Allah artinya neraka sedangkan berperang dengan Rasulullah artinya dengan pedang/senjata. ${ }^{26}$

Berdasarkan tafsir para mufassirin diatas maka sangat jelas bahwa riba berdampak pada kejiwaan manusia, berdampak pada harta manusia yaitu hancur/binasa/musnah/lenyap/merosot nilainya, dan berdampak diperangi Allah SWT dan rasul-Nya.

\section{Dampak Riba Menurut Hadits}

Hadits-hadits yang menerangkan dampak riba cukup banyak, namun untuk membatasi penelitian ini maka dipilihlah 5 hadits yang secara tegas menjelaskan dampak riba, antara lain:

\section{Pemakan riba, penyetor riba, penulis transaksi riba dan saksi yang menyaksikan transaksi riba dilaknat}

Dari Jabir bin Abdillah RA, Rasulullah SAW bersabda:

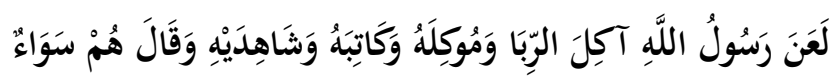

Artinya: Rasulullah SAW melaknat pemakan riba, penyetor riba, penulis transaksi riba dan saksi yang menyaksikan transaksi riba, semuanya sama. ${ }^{27}$

Diriwayatkan juga dengan matan berbeda dalam An-Nasa'i (5104) Ahmad (1364) Abu Dawud (2076), Al-Tirmidzi (1119), dan Ibn Majah (1935).

Yang dimaksud dengan pemakan riba contohnya rentenir, bank keliling, atau bank konvensional yang memakan bunga, termasuk orang yang menabung/menitipkan uang di lembaga itu. Penyetor riba adalah peminjam, debitur, atau nasabah yang meminjam, Penulis transaksi riba adalah sekretaris, notaris, karyawan yang menuliskan transaksi riba dan dua saksi yang menyaksikan transaksi riba.

\section{Riba mendatangkan azab kepada suatu negeri bukan hanya kepada pemakannya saja.}

Dari Abdullah bin Abas RA, Rasulullah SAW bersabda:

$$
\text { إذا ظهرَ الرِّنا و الرِبِا في قَرِةٍ ، فقد أَحَلُّوا بأنفسِهم عذابَ اللِِ }
$$

Artinya: Apabila zina dan riba muncul di suatu negeri, maka mereka telah menimpakan siksaan Allah SWT pada diri mereka sendiri. ${ }^{28}$

Berdasarkan hadits diatas maka azab dari riba bukan hanya menimpa para pelaku-pelaku riba saja tapi setiap orang yang ada disekitarnya juga, bahkan menimpa seluruh negeri.

\section{Riba merusak kehormatan orang lain}

\footnotetext{
${ }^{26}$ Al-Baghawi, Al-Husain bin Masúd. Ma’alim al-Tanzil,. Jilid. 1. Riyad: Dar al-Taybah, 1409.

${ }^{27}$ Muslim, Abul Husain bin al-Hajjaj, Shohih Muslim, Riyadh: Dar Taybah, 2006 Hadits Shohih No. 1598

${ }^{28}$ Al-Albani, Muhammad Nashiruddin, Shohih Al-Jami', Bairut: Al-Maktab Al-Islamiy, 1988 Hadits Shahih No. 279
} 
Dari Sa'ad bin Zaid RA, Rasulullah SAW bersabda:

$$
\text { إنَّ مِن أربَى الرِبِا الاستِطالةُ في عِرْضِ المسلٍِِ بغيرِ حقِّ }
$$

Artinya: Sesungguhnya seburuk-buruk riba adalah merusak kehormatan orang lain dengan cara yang tidak dibenarkan. ${ }^{29}$

Riba merusak kehormatan orang lain, antara lain karena merusak harkat dan martabat orang yang meminjam, membuat terhina dan malu, dengan riba yang jika tidak tertagih maka akan terus menumpuk-numpuk seiring waktu.

\section{Riba menjerumuskan kepada kemiskinan}

Dari Abdullah bin Mas'ud RA, Rasulullah SAW bersabda:

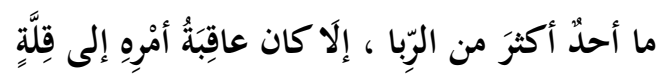

Artinya: Siapapun yang memperbanyak hartanya dari riba maka ujung akhir urusannya adalah kemiskinan. ${ }^{30}$

Riba akan membuat para pelakunya jatuh miskin, karena harus membayar lebih besar dari utangnya.

\section{Riba mendatangkan paceklik atau kekeringan}

Dari Amru bin Ash RA, Rasulullah SAW bersabda:

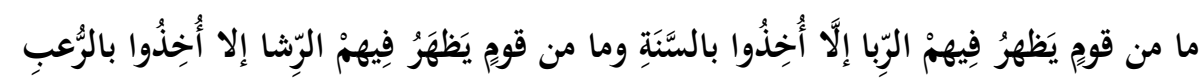

Artinya: Tidaklah riba merajalela pada suatu kaum kecuali akan ditimpa paceklik. Dan tidaklah budaya suap merajalela pada suatu kaum kecuali akan ditimpakan kepada mereka ketakutan. ${ }^{31}$

Dosa riba juga mendatangkan azab Allah berupa paceklik dan kekeringan, sehingga akan memperparah kondisi perekonomian.

\section{Kesimpulan}

Berdasarkan pembahasan diatas, dampak riba menurut Al-Quran dan Hadits antara lain:

1. Riba tidak akan menambah harta (Surat al-Rum ayat 39).

2. Riba menjerumuskan orang kedalam azab yang pedih sebagaimana yang ditimpakan kepada orang-orang yahudi (Surat an-Nisa ayat 160-161).

3. Riba berdampak pada kegagalan atau kejatuhan atau keruntuhan atau kesedihan dan atau kesusahan (Surat Ali 'Imran ayat 130).

\footnotetext{
${ }^{29}$ Al-Albani, Muhammad Nashiruddin, Shohih wa Dhoif At-Thargib wat Tarhib, Riyadh: Maktabah AlMa'arif, 2000 Hadits Shohih No. 2833

30 Al-Albani, Muhammad Nashiruddin, Shohih Al-Jami', Bairut: Al-Maktab Al-Islamiy, 1988 Hadits Shahih No: 5518 dan Ibnu Maajah, Sunan Ibnu Maajah, Kairo: Darut Taashil, 2014 Hadits No. 2279

${ }^{31}$ Al-Albani, Muhammad Nashiruddin, Shohih wa Dhoif At-Thargib wat Tarhib, Riyadh: Maktabah AlMa'arif, 2000 Hadits Dhoif No:1343
}

Ulumul Qur'an: Jurnal Ilmu Al-Qur'an dan Tafsir 
4. Riba berdampak pada kejiwaan manusia, berdampak pada hartanya yaitu hancur/binasa/musnah/lenyap/merosot nilainya, dan berdampak pada dirinya yaitu diperangi Allah SWT dan rasul-Nya (Surat al-Baqarah ayat 275, 276, 278, 279 dan 280).

5. Pemakan riba, penyetor riba, penulis transaksi riba dan saksi yang menyaksikan transaksi riba dilaknat (Shohih Muslim No. 1598).

6. Riba mendatangkan azab kepada suatu negeri bukan hanya kepada pemakannya saja (Shohih Al-Jami’ No. 279).

7. Riba merusak kehormatan orang lain (Shohih wa Dhoif At-Thargib wat Tarhib No. 2833).

8. Riba menjerumuskan kepada kemiskinan (Shohih Al-Jami' No: 5518 dan Sunan Ibnu Maajah Hadits No. 2279).

9. Riba mendatangkan paceklik atau kekeringan (Shohih wa Dhoif At-Thargib wat Tarhib No:1343).

Maka dari itu seyogyanya kita semua menghindari riba, karena dampak buruk yang ditimbulkannya.

\section{Daftar Pustaka}

Abdul Ghofur, Konsep Riba Dalam Al-Qur'an, Jurnal Economica Volume VII/Edisi 1/Mei 2016

Akmal,. Abidin, Zainal, Korelasi Antara Islam dan Ekonomi, Jurnal Penelitian, Vol. 9, No. 1, Februari 2015

Al-Albani, Muhammad Nashiruddin, Shohih Al-Jami', Bairut: Al-Maktab Al-Islamiy, 1988 Hadits Shahih No. 279

Al-Albani, Muhammad Nashiruddin, Shohih wa Dhoif At-Thargib wat Tarhib, Riyadh: Maktabah Al-Ma'arif, 2000 Hadits Shohih No. 2833

Al-Baghawi, Al-Husain bin Masúd. Ma’alim al-Tanzil,. Jilid. 1. Riyad: Dar al-Taybah, 1409.

Al-Mahally, Imam Jalaluddin dan Imam Jalaluddin As-suyutti, Tafsir Jalalain Berikut Asbab An-Nuzulnya, Bandung,: Sinar Baru, 1990

Al-Qurthubi, Ahmad Muhammad bin. Al-Jāmi' Li Ahkām Al-Qur'an. Bairut-Libnan: Muassasah al-Risālah, 2006

Al-Ṭhabarī, Abu Ja"ear Muḥammad Ibn Jarīr Ibn Yazīd Ibn Kathir Ibn Gālib . Jāmi'u al-Bayān fī Ta`wīli al-Qư’ān (Beirut: Daarul Kitab, 1412 H/1992 M)

Amin, Ahmad Riawan, Satanic Finance Bikin Umat Miskin, Jakarta: : Zaytuna Ufuk Abadi, 2012

Arif, Muhammad, Filsafat Ekonomi Islam. Fakultas Ekonomi dan Bisnis Islam. UIN Sumatera Utara, Buku DIKTAT, 2018

Ash-Shabuni, Syaikh Muhammad Ali, Shafwatut Tafasir Tafsir-Tafsir Pilihan, Jakarta, Pustaka Al-Kautsar, 2020.

As-Sa'di, Syaikh Abdurrahman bin Nashir. Taisirul Karimirrahman fi Tafsiri Kalamil Mannan. Cet. I; Baerut: Dar Ibn Hazm, 2003.

As-Syaukani, Muhammad bin Muhammad 'Alî bin Muhammad, Fathul Qodir al-Jami' Baina Fannair Riwayah Wad-Diroyah Min Ilmit Tafsir, Kairo:Darul Hadits, 1992

Ibnu Katsir, Tafsir al-Qur'an al-Adzim (Beirut : Daar al-Fikr, 1923)

Ibnu Maajah, Sunan Ibnu Maajah, Kairo: Darut Taashil, 2014 Hadits No. 2279

Muslim, Abul Husain bin al-Hajjaj, Shohih Muslim, Riyadh: Dar Taybah, 2006 Hadits Shohih No. 1598 
Oom Mukaromah, Interpretasi Ayat-Ayat Riba Dalam Kajian Tafsir Maudhu'i, AlQalam Vol 21, No.100 (Januari-April 2004)

Sanaky, Hujair A. H., Metode Tafsir (Perkembangan Metode Tafsir Mengikuti Warna atau Corak Mufassirin), Al-Mawarid Edisi XVIII Tahun 2008

Tho'in, Muhammad, Larangan Riba Dalam Teks Dan Konteks (Studi Atas Hadits Riwayat Muslim Tentang Pelaknatan Riba), Jurnal Ilmiah Ekonomi Islam Vol. 02 No. 02, Juli, 2016 